Original Research Article

\title{
Role of Emblica officinalis (amla) in the prophylaxis of hepatic injury by carbon tetrachloride $\left(\mathrm{CCl}_{4}\right)$ in albino rats
}

\author{
Chinmoyee Deori $^{1 *}$, Swarnamoni Das ${ }^{1}$, Sushanta Kumar Bordoloi ${ }^{2}$
}

\begin{abstract}
${ }^{1}$ Department of Pharmacology, Assam Medical College and Hospital (AMCH), Dibrugarh 786002, Assam, India

${ }^{2}$ Department of Pharmacology, Tezpur Medical College (TMCH), Tezpur, Assam, India
\end{abstract}

Received: 02 June 2017

Revised: 02 July 2017

Accepted: 03 July 2017

*Correspondence to:

Dr. Chinmoyee Deori,

Email: deorichinmoyee@ gmail.com

Copyright: () the author(s), publisher and licensee Medip Academy. This is an openaccess article distributed under the terms of the Creative Commons Attribution NonCommercial License, which permits unrestricted noncommercial use, distribution, and reproduction in any medium, provided the original work is properly cited.

\begin{abstract}
Background: The objective of the study was to evaluate the hepatoprotective activity of fruits extract of Emblica officinalis on carbon tetrachloride induced hepatotoxicity in Albino rats. Liver is vulnerable to wide variety of metabolic, toxic, microbial, circulatory and neoplastic insults. The dominant primary diseases of the liver are viral hepatitis, alcoholic liver disease and hepatocellular carcinoma. Due to absence of reliable drugs management of liver ailments in the modern medicine, plants and natural products are providing to be good hepatoprotectants as evident from voluminous published work on their hepatoprotective potentials.

Methods: The required amount of fresh fruits of Emblica officinalis was collected and dried at room temperature. The dried fruit ground into powdered and was prepared by percolation method using $95 \%$ ethanol. Acute oral toxicity test of the fruits extract was performed as per OECD 423 guidelines. Carbon tetrachloride was used as the hepatotoxin. Silymarin suspension $100 \mathrm{mg}$ was used as a standard drug in this study.

Results: The study was carried out with an attempt to evaluate the hepatoprotective activity of Emblica officinalis in carbon tetrachloride induced hepatic injury in albino rats. The results were analysed by using one way ANOVA followed by Dunnett's test and ( $\mathrm{p}<0.05)$ was considered significant.

Conclusions: The present study shows that the Emblica officinalis has significant hepatoprotective activity in rats with carbon tetrachloride induced liver injury. Emblica officinalis is a commonly used traditional herb, which is safe, cost effective and grows widely in India and used by different ethnic groups for various diseases. That is why Emblica officinalis, a commonly used natural herb, deserve further consideration in order to establish its potential as safe economical hepatoprotective agent.
\end{abstract}

Keywords: Air tight container, Carbon tetrachloride, Drier table, Fruit extract of Emblica officinalis, 95\% ethyl alcohol, Percolator, Silymarin

\section{INTRODUCTION}

Xenobiotic can produce a diverse group of hepatic lesions that mimic virtually any form of hepatic disease, from viral hepatitis and cirrhosis to vascular occlusion and portal hypertention.It is estimated that $5 \%$ of cases of jaundice are due to drugs, and the therapeutic agents cause $25 \%$ fulminant hepatitis. ${ }^{1}$ Emblica officinalis is one of the most celebrated herbs in Indian traditional system, Ayurveda. It is found natively in India. It has been used as valuable ingredient of various medicines in India and abroad.
Emblica officinalis is a small to medium sized tree, deciduous; branchlets feathery with distichously leaves, resembling a pinnate leaf. Bark greyish or light brownish, exfoliating in irregular plates; blaze pinkish brown to reddish green at the edge, $0.25-0.5$ inch thick. $^{2}$

\section{Plant extract}

The plant was authenticated by Prof. M. Islam, Dept. of Life Sciences, Dibrugarh University, Assam. 
The required amount of fresh fruits of Emblica officinalis were collected and dried in a drier table at room temperature. The dried fruit ground into a powder. Sufficient amount of powered drug was moised with $95 \%$ ethyl alcohol and allowed to remain for 6 hours in tightly covered container. Then they were packed in a percolator and add enough menstrum to saturate the powders. When the liquid begins to drop from the percolator, the lower orifice is closed and the percolator macerate is covered for 48 hours. Percolator was then allowed slowly with sufficient menstrum, until the drugs is exhausted. Then, the residue obtained from percolation was put in vacuum desiccators. $^{3}$

\section{Animals}

All the animals used in the study were procured from Central Animal House, Assam Medical College and Hospital, Dibrugarh, Assam. The study was conducted in accordance with CPCSEA (Committee for the Purpose of Control and Supervision of Experiment on Animals) guidelines. They were fed with standard diet and water $a d$ libitum was provided. Experimental animals used were healthy albino rats of the species Rattus norvegicus of either sex weighing 150-200gm.

\section{Acute toxicity study}

Acute toxicity test was done for the ethanolic extract of Emblica officinalis following OECD 425 guidelines. ${ }^{4}$ An arbitrary dose $200 \mathrm{mg} / \mathrm{kg}$ was selected for the study, as the extract was found safe even at doses more than $2000 \mathrm{mg} / \mathrm{kg}$ without any sign of toxicity or mortality.

\section{METHODS}

Silymarin tablets were collected and crushed into powder. The stock solution was prepared by dissolving 100mg of Silymarin in $5 \mathrm{ml}$ of normal saline and used as a standard drug in doses of $100 \mathrm{mg} / \mathrm{kg}$ body weight/day.

Carbon tetrachloride $0.5 \mathrm{ml} / \mathrm{kg} / \mathrm{body}$ weight with olive oil $1: 1$ volume was prepared and was used as the hepatotoxin. Liver damage was induced in Albino rats with 1:1 (v/v) mixture of carbon tetrachloride in olive oil, administered at the dose of $0.5 \mathrm{ml} / \mathrm{kg} /$ body weight subcutaneously.

The experiment was carried out for a period of 14 days. For the experiment, the animals were weighted, recorded, numbered and randomly divided into 4 groups of 6 animals each.

- Group I: Received only normal saline $5 \mathrm{ml} / \mathrm{kg}$ orally 7 days.

- Group II: Received carbon tetrachloride $0.5 \mathrm{ml} / \mathrm{kg} /$ body weight with olive oil 1:1 volume subcutaneously for 7 days + normal saline for 7 days.

- Group III: Received carbon tetrachloride $0.5 \mathrm{ml} / \mathrm{kg} /$ body weight with olive oil 1:1 volume subcutaneously + Emblica officinalis extract (EOE) $200 \mathrm{mg} / \mathrm{kg} /$ body weight orally for 7 days.

- Group IV: Received carbon tetrachloride $0.5 \mathrm{ml} / \mathrm{kg} /$ body weight with olive oil 1:1 volume subcutaneously + Silymarin suspension $100 \mathrm{mg} / \mathrm{kg} /$ body weight orally for 7 days.

\section{RESULTS}

The study was carried out with an attempt to evaluate the hepatoprotective activity of Emblica officinalis in the prophylaxis of hepatic injury by carbon tetrachloride in albino rats. In the study, the efficacy of Emblica officinalis was compared with standard known hepatoprotective agent, Silymarin. The statistical significance between groups was analysed using one way ANOVA followed by dunnett's and bonferroni test. The significance was expressed by ' $p$ ' values as mentioned in the tables. $P$ value of $<0.05$ was considered significant. Table 1 shows all the parameters are not significantly increased in prophylactically treated group (group III) in comparison to carbon tetrachloride treated group (group II). But there is no significant difference between group III and group IV.

Table 1 shows all the parameters are not significantly increased in prophylactically treated group (group III) in comparison to carbon tetrachloride treated group (group II). But there is no significant difference between group III and group IV.

Table 1: One way ANOVA followed by Dunnett's test and Bonferroni test.

\begin{tabular}{|c|c|c|c|c|c|}
\hline Group & Serum alkaline phosphatase & AST & ALT & Total protein & Albumin globulin ratio \\
\hline I (control) & $12.6 \pm 0.09$ & $28 \pm 1.66$ & $12 \pm 1.53$ & $6.4 \pm 0.18$ & $1.5 \pm 0.08$ \\
\hline $\mathrm{II} \mathrm{CCl}_{4}$ & $22.6 \pm 0.49^{a}$ & $60 \pm 1.41^{\mathrm{a}}$ & $40 \pm 1.15^{\mathrm{a}}$ & $50 \pm 0.02^{\mathrm{a}}$ & $0.3 \pm 0.09^{\mathrm{a}}$ \\
\hline $\mathrm{III}\left(\mathrm{CCl}_{4}+\mathrm{EO}\right)$ & $14.0 \pm 0.93^{b}$ & $24 \pm 0.93^{b}$ & $17 \pm 0.95^{b}$ & $5.6 \pm 0.09^{b}$ & $0.6 \pm 0.24^{\mathrm{b}}$ \\
\hline IV $\left(\mathrm{CCl}_{4}+\right.$ sily $)$ & $13.4 \pm 0.09^{b}$ & $26 \pm 1.56^{b}$ & $16 \pm 1.56^{b}$ & $5.8 \pm 0.12^{b}$ & $1.3 \pm 0.09^{\mathrm{b}}$ \\
\hline ANOVA & $\begin{array}{l}F 10.39 \\
\text { df3, } 20 \\
P<0.05\end{array}$ & $\begin{array}{l}\text { F387.59 } \\
\text { df3, } 20 \\
P<0.05\end{array}$ & $\begin{array}{l}\text { F } 67.40 \\
\text { df } 3,20 \\
P<0.05\end{array}$ & $\begin{array}{l}\text { F26.25 df3, } \\
20 \\
P<0.05\end{array}$ & $\begin{array}{l}\text { F 29.08 } \\
\text { df3, } 20 \\
P<0.05\end{array}$ \\
\hline
\end{tabular}

Values are expressed as SEM $(\mathrm{n}=6)$

${ }^{\mathrm{a}} \mathrm{p}<0.05$, when compared to the Normal Control Group

${ }^{\mathrm{a}} \mathrm{p}<0.05$, when compared to the Experimental Control Group 
Table 1 shows the Serum Alkaline Phosphatase level in different groups. The Serum Alkaline Phosphatase level of rat exposed to $\mathrm{CCL}_{4}$ group II on $7^{\text {th }}$ day was $22.6 \pm 0.49$ (P $<0.05)$. The Serum Alkaline Phosphatase level of group III $\left(\mathrm{CCL}_{4}\right.$ with EO) for 7 days was $14 \pm 0.93$ (P <0.05). The Serum Alkaline Phosphatase level of group IV $\left(\mathrm{CCL}_{4}\right.$ with Silymarin) for 7 days was $13.3 \pm 0.09$ (P <0.05). The AST level in different groups. The AST level of rat exposed to $\mathrm{CCL}_{4}$ group II on $7^{\text {th }}$ day was $60 \pm 1.41(\mathrm{P}<0.05)$. The AST level of group III (CCL 4 with EO) for 7 days was $24 \pm 0.93$ (P <0.05). The AST level of group IV $\left(\mathrm{CCL}_{4}\right.$ with Silymarin) for 7 days was $26 \pm 1.56$ ( $\mathrm{P}<0.05)$. The ALT level in different groups. The ALT level of rat exposed to $\mathrm{CCL}_{4}$ group II on $7^{\text {th }}$ day was $40 \pm 1.15(\mathrm{P}<0.05)$. The ALT level of group III (CCL4 with EO) for 7 days was $27 \pm 0.95$ ( $\mathrm{P}<0.05)$. The ALT level of group IV $\left(\mathrm{CCL}_{4}\right.$ with Silymarin) for 7 days was $16 \pm 1.56(\mathrm{P}<0.05)$. The Albumin Globulin Ratio in different groups. The Total Protein level in different groups. The Total Protein level of rat exposed to $\mathrm{CCL}_{4}$ group II on $7^{\text {th }}$ day was $50 \pm 0.02(\mathrm{P}<0.05)$. The Total Protein level of group III ( $\mathrm{CCL}_{4}$ with EO) for 7 days was 5.6 \pm 0.09 ( $\mathrm{P}<0.05)$. The Total Protein level of group IV (CCL 4 with Silymarin) for 7 days was 5.8 \pm 0.12 (P $<0.05)$. The Albumin Globulin Ratio in different groups. The Albumin Globulin Ratio level of rat exposed to $\mathrm{CCL}_{4}$ group II on $7^{\text {th }}$ day was $0.3 \pm 0.09(\mathrm{P}<0.05)$. The Albumin Globulin Ratio level of group III $\left(\mathrm{CCL}_{4}\right.$ with $\left.\mathrm{EO}\right)$ for 7 days was 0.6 $\pm 0.24(\mathrm{P}<0.05)$. The Albumin Globulin Ratio of group IV $\left(\mathrm{CCL}_{4}\right.$ with Silymarin) for 7 days was $1.3 \pm 0.09(\mathrm{P}<0.05)$.

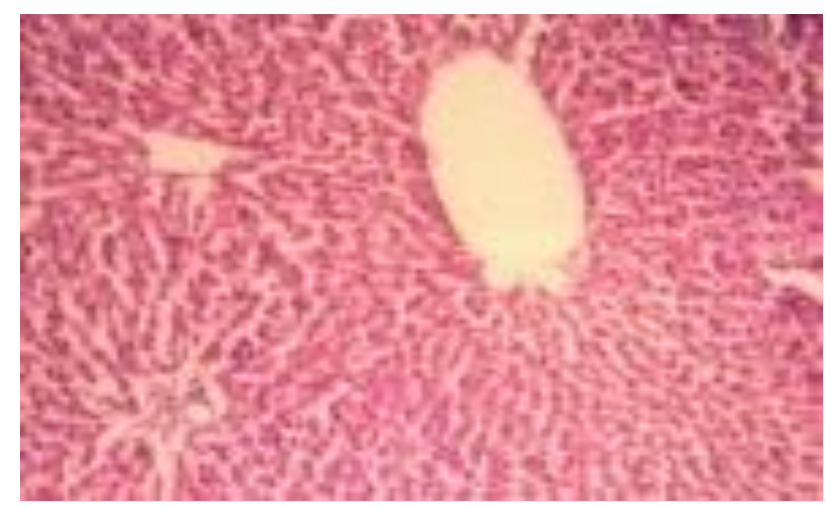

Figure 1: Normal hepatic cells.

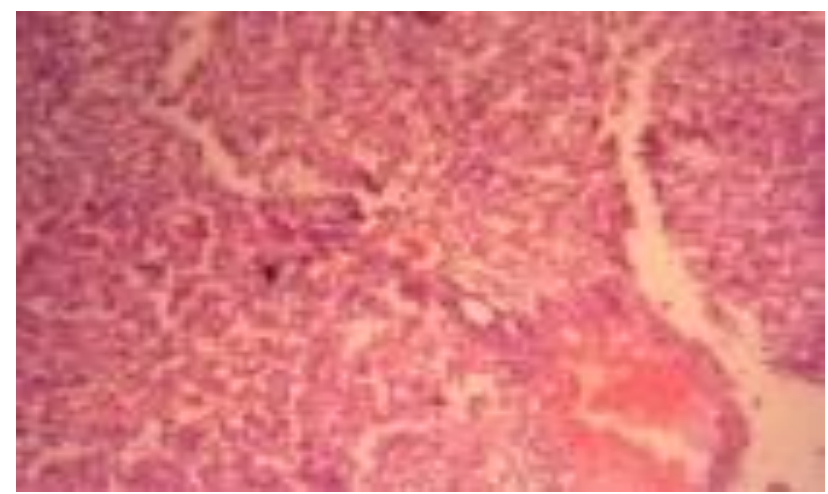

Figure 1 shows normal hepatic cells. Figure 2 shows carbontetrachloride $\left(\mathrm{CCl}_{4}\right)$ treated areas of hepatic injury.

Figure 3 shows carbontetrachloride $\left(\mathrm{CCl}_{4}\right)$ and Emblica officinalis treated group showing less hepatic injury than carbontetrachloride $\left(\mathrm{CCl}_{4}\right)$ treated group.

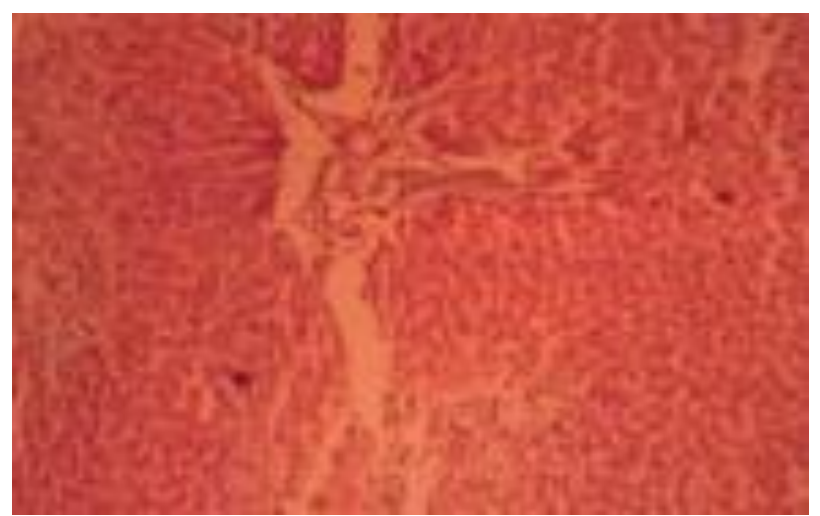

$\mathrm{CCl}_{4}+$ Emblica officinalis treated shows less hepatic injury with regenerative areas

Figure 3: $\mathrm{CCl}_{4}+$ Emblica officinalis.

Figure 4 shows carbontetrachloride $\left(\mathrm{CCl}_{4}\right)$ and Silymarin treated group showing less hepatic injury than only carbontetrachloride treated group $\left(\mathrm{CCl}_{4}\right)$. Both groups $\left(\mathrm{CCl}_{4}+\right.$ Emblica officinalis and $\mathrm{CCl}_{4}+$ Silymarin) showing less hepatic injury with some regenerative areas of hepatic cells.

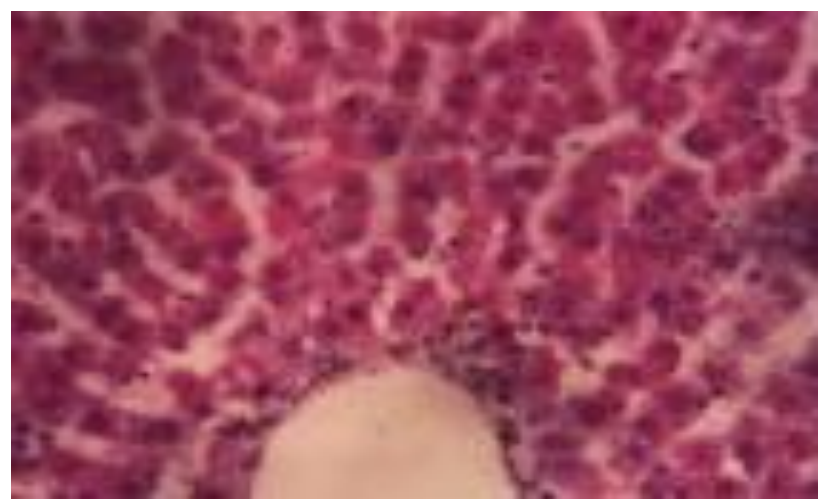

$\mathrm{CCl}_{4}+$ SILYMARIN treated shows less hepatic injury with regenerative areas

Figure 4: $\mathrm{CCl}_{4}+$ Silymarin.

\section{DISCUSSION}

The purpose of the study was to evaluate the hepatoprotective activity of the alcoholic extract of the fruit of Emblica officinalis to a standard drug Silymarin on carbon tetrachloride induced hepatotoxicity in Albino rats.

The statistical analysis was done by using one way ANOVA test followed by Dunnet's test. Values of $<0.05$ were considered significant.

Figure 2: $\mathrm{CCl}_{4}$ Treated hepatic cells. 
Carbon tetrachloride $\left(\mathrm{CCl}_{4}\right)$ is a synthetic compound also known as tetrachlormethane, is a synthetic compound formerly used in fire extinguishers and refrigeration, but now largely abandoned due to its toxicity.

The experimental intoxication induced by carbon tetrachloride $\left(\mathrm{CCl}_{4}\right)$ is widely used for modelling liver injury in rats. Hepatotoxicity is connected with severe impairment of cell protection mechanisms. The location of the liver injury is defined mainly by biotransformation of $\mathrm{CCl}_{4}$, which is cytochrome $\mathrm{P}_{450}$ dependent. Free radicals initiate the process of lipid peroxidation, which is generally caused of inhibition of enzyme activity. ${ }^{5}$

In this study liver damage produced by carbon tetrachloride was confirmed by analysis of different levels of enzymes and histopathological examination of liver when compared with control group.

The histological profile of control animal showed normal hepatocytes, the section of the liver of the group II carbon tetrachloride treated group exhibited severe intense centrilobular necrosis, vascuolization and macro vesicular fatty changes. The liver section of the animals treated with alcoholic extract of Emblica officinalis showed almost normal architecture as compared to $\mathrm{CCl}_{4}$ treated group.

Antioxidant activity or the inhibition of the generation of free radicals is important against $\mathrm{CCl}_{4}$ induced liver lesion. ${ }^{6}$

Flavonoids are well known for their antioxidant and hepatoprotective activities. ${ }^{7}$ Quercetin a bioflavanoid prevent in Emblica officinalis has been reported to prevent cytotoxicity in isolated hepatocytes by $\mathrm{CCl}_{4}{ }^{8}$

The tannoids of Emblica officinalis have been reported to enhance reactive oxygen species (ROS) scavenging activity in rat brain frontal cortex and straiatum enhanching the concentrations of the antioxidant enzymes SOD, catalase (CAT) and glutathione peroxidise (GPX) resulting in reduced lipid peroxidation. ${ }^{9}$

Phytochemicals screening revealed that Emblica officinalis contains active pharmacological constituents such as flavonoids, alkaloids, phytosterols and phenolic compounds. However, it has been already reported that such phytoconstituents like phenolic compounds, flavonoids, tannins are known to posses' hepatoprotective activity in various experimental models. Therefore, it has been suggesting that the hepatoprotective activity may be due to these active phytoconstituents present in the plant which is being also confirmed by the biochemical and histological parameters. ${ }^{10}$

Several other compounds like polyphenols, ellagic acid, gallic acid and tannins are present in very high amount along with vitamin C. ${ }^{11}$

\section{ACKNOWLEDGEMENTS}

Authors would like to thank Dr. M. Islam, Department of life sciences, Dibrugarh University, Assam, for helping them with taxonomical identification of the plant and Dr. (Mrs.) M. Buragohain, Department of Pathology, for helping us with histopathological examination.

Funding: No funding sources

Conflict of interest: None declared

Ethical approval: The study was approved by the Institutional Animal Ethics Committee (634/02/a/CPCSEA)

\section{REFERENCES}

1. Lipscomb MF. The liver and biliary tract. In: Kumer V, Cotran RS, Robbins. Basic Pathology. W.B Saunders company, Harcout. $5^{\text {th }}$ Ed.; 1992:523-567.

2. Knjilal UN, Kanjilal PC, De RN, Das. A Flora of Assam; 1940:159-160.

3. Pharmaceutical Formulas. Chemist and Druggist $.11^{\text {th }}$ Edition; 1950:1,183.

4. OECD. OECD Guidelines for Testing of Chemicals [internet]. France: OECD Publishing; 2006. Section 4, Health effects: Test No. 425: Acute oral toxicity: Up and down procedure (Adopted 2006. March 23).

5. Mac Cay PB, Lai EK, Poyer JL. Oxygen and carboncentered free radical formulation during carbon tetrachloride metabolism observation of lipid radical in vivo and in vitro. J. Biol. Chem. 1984;259:2135-43.

6. Johnston DE, Kroening C. Mechanism of early carbon tetrachloride toxicity in cultured rats hepatocytes. Pharmacol Toxicol. 1998;39:231-9.

7. Back NL, KmYS, Kyung JS, Park KH. Isolation of antihepatotoxicity agent from the roots of Astragalus membranaceous, Korean J pharmacog. 1996;27:111.

8. Gulati RK, Agarwal S, Agarwal SS. Hepatoprotective studies on Phyllanthus Emblica linn and quercetin. Ind J. Exp. Biol. 1995;33:261.

9. Paya M, Ferrandiz ML, Sanz MJ, Alcaraz MJ. Effects of phenolic compounds on bromobenzene mediated hepatotoxicitynin mice, Xenobiotics. 1993;23:327.

10. Bhattacharya A, Chatterjee A, Ghosal S, Bhattacharya SK. Antioxidant activity of active tannoid principles of Emblica officinalis (amla). Ind $J$ Exp Bio. 1999;37:676-80.

11. Gopalan C, Sastri RBV, Balasubramanian SC, Rao NBS, Deosthale YG, Pant KC. eds. Nutritive value of Indian foods. Hyderabad: National Institute of Nutrition, (ICMR), 1989.

Cite this article as: Deori C, Das S, Bordoloi SK. Role of Emblica officinalis (amla) in the prophylaxis of hepatic injury by carbon tetrachloride $\left(\mathrm{CCl}_{4}\right)$ in albino rats. Int J Basic Clin Pharmacol 2017;6:19925 . 